\title{
The Roles of Construction Professionals in the Nigeria's Construction Industry
}

\author{
Olanrewaju Sharafadeen Babatunde Owolabi ${ }^{1}$, Akinpelu Samuel Olatunji ${ }^{2}$ \\ Department of Building Technology, School of Environmental Studies, The Federal Polytechnic, Ado Ekiti, Ekiti \\ State, Nigeria.
}

\begin{abstract}
The study traced the history of construction industry, surveyed its development at the present time and described the intensity of competition and roles of each professional among the existing professionals in the Nigeria's construction industry. Data for the study were collected through well-structured questionnaire directed to construction professionals in the private and public sectors. Data collected were analyzed using frequency distribution table and relative significance index. It revealed that the roles of the Architect are to produce detailed working drawings and specifications (93\% significance). The roles of the Builders are to ensure the adequate preparation of project health and safety (94\% significance), preparation of construction methodology (93\%), preparation of construction programme (90\%), and preparation of project quality and management (86\%). The Estate surveyors and Valuers are to prepare the valuation of construction works (91\% significance), preparation of feasibility and viability appraisal of construction projects (81\%), and Construction project management (70\%). The Engineer on the other hand is to calculate the load and stresses that the structure can safely withstand (99\% significance). The Land Surveyor performs building location survey (96\% significance), Provides site plan (73\%), Foundation location (69\%), and Prepare construction layout (67\%). Furthermore, the Town planner's roles are to prepare Road utility design survey (95\% significance), Design layout and draft design statement (94\%), and Protect environment and architectural heritage (89\%). The roles of the Quantity surveyor are to prepare bill of quantities (100\% significance), Estimate cost relating to construction materials, time and labour and cost advise (94\%), Variation of work in progress and materials on site for interim payment (87\%), The study recommended that there should be strict regulations and implementation of laws by the body of each profession guiding against function overlap among the professionals in the construction industry.
\end{abstract}

\section{Introduction}

The building construction industry is as old as human civilization itself. The history of the industry evolves with evolution of human settlements and culture. It has its different feature in each age of human existence namely agrarian, industrial and information ages.

As such the building construction industry has over time, in an attempt to overcome evolving challenges as a result of increasing complexity of human settlement( town, country, city, megacity), culminated into specialization that seek to enhance efficiency and economical service delivery in the industry.

[1] reports that construction is one of the most important activities of any economy and a large proportion of the country's resources are usually used in the construction and maintenance of building. The construction sector in Nigeria accounts for 3-8\% of Gross Domestic Product (GDP), about 5\% of the labour force, $40-70 \%$ of the gross fixed capital formation and about $12 \%$ of industrial sector production [2]. This enormous amount of wealth is managed or generated by the construction industry through the various contributions of its professional members. [3] ascertained that the construction industry is a viable sector in the economy of any country.

The present state of construction industry is complex. There is a wide range of construction products and system which are aimed primarily at groups of infrastructure types or markets. The design process for an infrastructure is highly organized and draws upon research establishments that study materials properties and performance, codes officials who adopt and enforce safety standards, and design professionals who determine user needs and design variety of infrastructure and facility to meet those needs. The construction process is also highly organized; it includes the manufacturers of construction products and system, the craftsmen, the contractors and consultants who specialize in such aspects as construction management, quality control, and insurance.

Construction industry plays a substantial role in a country's economy, irrespective of the country's level of development. The construction sector in a country's economy is an important employer of a nation's workforce as it employs between 2 to $10 \%$ of total workforce of most countries [4]. Nigeria had gained an impressive economic growth during the last decades. The construction industry plays an important role in the 
transformation of the physical terrain of any nation in its march toward greater civilization and economic independence. It is also concerned with the assimilation and utilization of exogenous development in technology, management sciences and related sciences to enhance building performance to win the world over [5].

\section{Literature Review}

The construction of a building project of any kind involves the services of many people, directly, who design, construct and maintain it from inception to completion, and to terminal demolition [6]. It is important to understand the term "profession" before discussing the issue of professionalism in depth. [7] defined profession as an occupation requiring extensive education i.e. an occupation that requires extensive education or specialized training. Profession is a skilled occupation, usually one requiring specific education, training, knowledge or experience [8].

According to [9], the essence of the word "professionalism" can be defined as the possession and autonomous control of a body of specialized knowledge, which when combined with honorific status, confers power upon its holders.[7] described professionalism as the professional standards that involved the skill, competence, or character expected of a member of a highly trained profession. Professionalism can also be defined as professional standards involving the exercising of body of unique, expert and knowledge. Professionals have always been linked with the notion of "service" so that a professional is described as a group of people organised to serve a body of specialized knowledge in the interests of society based on the perceived relationship [10]. [11] stated that professional is automatically tied up with more practical concepts and expectations from the public, encompassing issues such as competence, responsibility and willingness to serve the public. [12] feels that the problem that faces any professional community is how it could regulate itself effectively to justify its autonomy, while ensuring that the clients of its members and society as a whole benefit from the profession's and the individual professional's actions, rather than becoming their victims. It is one of the ethical quality control. Construction industry plays a substantial role in a country's economy, irrespective of the country's levels of economic development [13]. The construction sector in a country's economy is an important employer of a nation's workforce as it employs between 2 to $10 \%$ of total workforce of most countries [4]. Nigeria had gained an impressive economic growth during the last three decades.

Therefore the list of the professionals actively involved in the construction industry includes but not limited to, Architects, Builders, Estate surveyors and valuers, Land surveyors, Quantity surveyors, Town planners, Civil, Electrical, Mechanical and Structural Engineers. To achieve the purpose of this study, seven of these professionals were selected; they include the architect, builder, estate surveyor and valuers, engineer land surveyor, town planner and quantity surveyor.

Construction industry everywhere faces problem and challenges. These difficulties and challenges are present alongside a general situation of institutional weakness, professional rivalry among others. Many topic issues which have implications for the construction industry have, so far, only been discussed to a significant extent.

\section{Methodology}

The study population comprised the construction professionals in the private and public service in the Nigerian construction industry. This involved assessing professional views. The study deals with the roles of construction professionals in the Nigeria construction industry. Two hundred (200) questionnaires were directly distributed with the intention of eliciting response from the public and private organisations toward determining the roles of construction professionals in carrying out construction project.

The Likert scale involving rating on interval scale of 5 and 1 developed for application in social science and management research for quantification of qualitative variable was used for the data collection.

The statistical tools used for analysis include percentage, mean, and relative significance index (RSI). The relative significance ranking (RSI) was used for ranking of the factors studied. These methods have been used in construction research by authors such as, [14], [15], [16], [17], [18] among others.

The responses of the items on the questionnaire were obtained on a 5-point scale ranging from 1 to 5 . "Strongly Agree" were scored 5, "Agreed" were scored 4, "Undecided"' were scored 3, "Disagreed" were scored 2 and "Strongly Disagreed" were scored 1.

Relative Significance Index (RSI) is a non-parametric technique based on the aggregate weighting of the initial frequency score of factors. The Relative significance index was computed as

$$
\text { RSI }=\frac{\sum_{\mathrm{j}=1}^{\mathrm{n}=5} \text { nik } i}{\sum \mathrm{jN}}=\frac{5 \mathrm{n} 5+4 \mathrm{n} 4+3 \mathrm{n} 3+2 \mathrm{n} 2+1 \mathrm{n} 1}{\sum \mathrm{jN}} \text { i.e. }(0<\text { index }<1)
$$

Where:

$\mathrm{ni}=$ the number of respondents choosing $\mathrm{ki}_{=} 1-5$ on the Likert scale; 
$\sum \mathrm{N}=$ the total of questionnaire collected (sample size);

$\mathrm{j}=$ the highest value in ranking order;

$\mathrm{N}=$ the total number of responses.

\section{Data analysis and results}

The data obtained are hereby analysed and the results presented. The analysis tools include both the descriptive and inferential.

\subsection{Respondents' profile}

Table 1 shows the professional qualifications of respondents. The respondents cut across various professional qualifications such as ARCON, CORBON, ESVRBON, COREN, SURCON, TOPREC, QSBORN, and other related professional qualifications

Table 1: Professional qualification

\begin{tabular}{llll}
\hline Qualification & Frequency & Percentage & \\
\hline ARCON & 22 & 11.00 & \\
CORBON & 26 & 13.00 & \\
ESVRBON & 20 & 10.00 & \\
COREN & 23 & 11.50 & \\
SURCON & 19 & 9.50 & \\
TOPREC & 21 & 10.50 & \\
QSRBN & 24 & 12.00 & 22.50 \\
Others & 45 & & \\
\hline Total & 200 & 100.0 & \\
\hline
\end{tabular}

Table 2 shows the academic qualifications of respondents. 45 percent of the respondents have Higher National Diploma (HND) degree, 15 percent have Post-graduate Diploma (PGD) degree, 12.50 percent have Bachelor of Science (B.Sc.) degree, 10 percent have Bachelor of Engineering (B.Eng.) degree, 10 percent have National Diploma (ND) degrees and 7.50 percent have Masters (M.Sc.) degree.

Table 2: Academic qualifications

\begin{tabular}{lll}
\hline Qualification & Frequency & Percentage \\
\hline B.Eng & 20 & 10.00 \\
B.Sc. & 25 & 12.50 \\
HND & 90 & 45.00 \\
M.Sc. & 15 & 7.50 \\
ND & 20 & 10.00 \\
PGD & 30 & 15.00 \\
\hline Total & $\mathbf{2 0 0}$ & $\mathbf{1 0 0}$ \\
\hline
\end{tabular}

Table 3 shows the post held by respondents in their respective organizations. It showed that 21 percent are Builders/Estimators, 20 percent are Lecturers, 19 percent are Managers, 17.50 percent are Engineers, 12.50 percent are Quantity surveyors and 10 percent are Technical officers in the organisations.

Table 3: Post held

\begin{tabular}{lll}
\hline Post & Frequency & Percentage \\
\hline Engineer & 35 & 17.50 \\
Builder/Estimator & 42 & 21.00 \\
Manager & 38 & 19.00 \\
Lecturer & 40 & 20.00 \\
Technical Officer & 20 & 10.00 \\
Quantity Surveyor & 25 & 12.50 \\
\hline Total & $\mathbf{2 0 0}$ & $\mathbf{1 0 0}$ \\
\hline
\end{tabular}

\subsection{Roles of professionals in the Nigeria`s construction industry}

\subsubsection{Architect}

Table 6 identified the various roles of an architect among the professionals in the construction industry and the ranking of the factors through the use of Relative Significance Index (RSI).

Table 6: Roles of the architect in the Nigerian construction industry

\begin{tabular}{|c|c|c|c|c|c|c|c|c|c|}
\hline Roles & 1 & 2 & 3 & 4 & 5 & Total & TWV & RSI & Rank \\
\hline Preparing application for planning and building control & 10 & 25 & 10 & 25 & 130 & 200 & 840 & 0.84 & 3 \\
\hline Producing detailed working drawing and specification & 0 & 5 & 0 & 60 & 135 & 200 & 925 & 0.93 & 1 \\
\hline Cost analysis and land-use study & 15 & 120 & 45 & 10 & 10 & 200 & 480 & 0.48 & 5 \\
\hline Turning the client brief into drawing & 0 & 5 & 5 & 60 & 130 & 200 & 915 & 0.92 & 2 \\
\hline Final construction plans & 0 & 5 & 45 & 90 & 60 & 200 & 805 & 0.81 & 4 \\
\hline
\end{tabular}


The survey revealed that Producing detailed working drawing and specification ranked first with RSI value of 0.93 (i.e. 93 percent significance) among the roles of the architects in the Nigerian construction industry. Turning the client brief into drawing ranked second with RSI value of 0.92. Preparing application for planning and building control ranked third with RSI value of 0.84 . These are followed by Final construction plans (0.81), and Cost analysis and land-use study (0.48). The result also showed that all the roles are significant with the least role having $48(0.48)$ percent significance.

\subsubsection{Builders}

Table 7 investigated the various roles of the Builders among the professionals in the construction industry and the ranking of the factors through the use of Relative Significance Index (RSI).

Table 7: The roles of the builder in the Nigerian construction industry

\begin{tabular}{llllllllll}
\hline Roles & $\mathbf{1}$ & $\mathbf{2}$ & $\mathbf{3}$ & $\mathbf{4}$ & $\mathbf{5}$ & Total & TWV & RSI & Rank \\
\hline Preparing construction programme & 0 & 5 & 35 & 20 & 140 & 200 & 895 & 0.90 & 3 \\
Preparing of project health and safety plan & 0 & 10 & 10 & 15 & 165 & 200 & 935 & 0.94 & 1 \\
Preparing construction methodology & 0 & 0 & 0 & 75 & 125 & 200 & 925 & 0.93 & 2 \\
Preparing of project quality management plan & 0 & 35 & 0 & 35 & 130 & 200 & 860 & 0.86 & 4 \\
\hline
\end{tabular}

This analysis revealed that Preparation of project Health and Safety plan ranked first with RSI value of 0.94 (i.e. 94 percent significance), Preparing construction methodology ranked second with RSI value of 0.93 , Preparing construction programme ranked third with RSI value of 0.90, and Preparation of Project Quality Management plan ranked fourth with RSI value of 0.86 . The result also showed that all the roles are significant with the least role having $86(0.86)$ percent significance.

\subsubsection{Estate surveyors and valuers}

Table 8 identified the various roles of an estate surveyor and valuers among the professionals in the construction industry and the ranking of the factors through the use of Relative Significance Index (RSI).

Table 8: The roles of the estate surveyors and valuers in the Nigerian construction industry

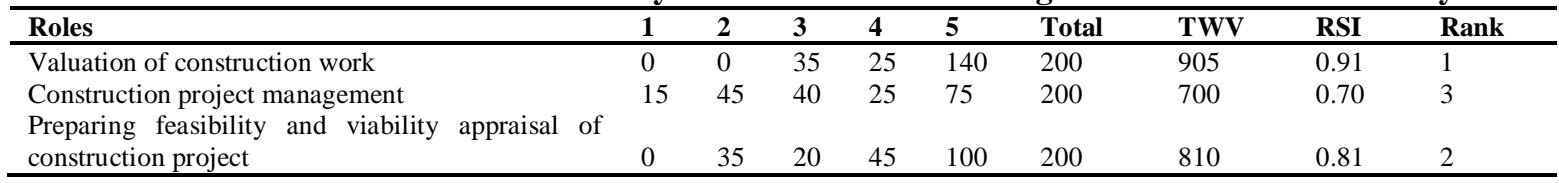

The roles of the estate surveyors and valuers in the Nigerian construction industry revealed that Valuation of construction work ranked first with RSI value of 0.91 (i.e. 91 percent significance), Preparing feasibility and viability appraisal of construction project ranked second with RSI value of 0.81 , and Construction project management ranked third with RSI value of 0.70 . The result also showed that all the roles are significant with the least role having $70(0.70)$ percent significance.

\subsubsection{Engineers}

Table 9 identified the various roles of an engineer among the professionals in the construction industry and the ranking of the factors through the use of Relative Significance Index (RSI).

Table 9: Relative Significance Index (RSI) of the roles of the engineers in the Nigerian construction industry

\begin{tabular}{|c|c|c|c|c|c|c|c|c|c|}
\hline Roles & 1 & 2 & 3 & 4 & 5 & Total & TWV & RSI & Rank \\
\hline $\begin{array}{l}\text { Calculation of load and stresses the construction will safely } \\
\text { withstand }\end{array}$ & 0 & 0 & 5 & 10 & 185 & 200 & 975 & 0.98 & 1 \\
\hline Factorizing the qualities and strength of building materials & 0 & 10 & 0 & 95 & 95 & 200 & 875 & 0.88 & 4 \\
\hline Incorporating structural members and foundation & 0 & 30 & 10 & 60 & 100 & 200 & 830 & 0.83 & 5 \\
\hline Determining the suitability of the earth for construction & 0 & 10 & 70 & 45 & 75 & 200 & 785 & 0.79 & 6 \\
\hline $\begin{array}{l}\text { Organization and delivery of materials and equipment for } \\
\text { construction }\end{array}$ & 5 & 85 & 40 & 10 & 60 & 200 & 635 & 0.64 & 7 \\
\hline $\begin{array}{l}\text { Management and supervision of on-site labour } \\
\text { Installing and maintain mechanical machinery, tool and }\end{array}$ & 15 & 65 & 50 & 20 & 50 & 200 & 630 & 0.63 & 8 \\
\hline component in a building & 0 & 5 & 5 & 5 & 185 & 200 & 970 & 0.97 & 2 \\
\hline Installing and maintaining electrical control system & 0 & 10 & 0 & 40 & 150 & 200 & 930 & 0.93 & 3 \\
\hline
\end{tabular}

The roles of engineers in the Nigerian construction industry revealed that Calculation of load and stresses the construction will safely withstand ranked first with RSI value of 0.99 (i.e. 99 percent significance), Installing and maintain mechanical machinery, tool and component in a building ranked second with RSI value of 0.97 , and Installing and maintaining electrical control system ranked third with RSI value of 0.93 . These are followed by Factorizing the qualities and strength of building materials (0.88), Incorporating structural members and foundation (0.83), Determining the suitability of the earth for construction (0.79), Organization and delivery 
of materials and equipment for construction (0.64), and Management and supervision of on-site labour (0.63). The result also showed that all the roles are significant with the least role having $63(0.63)$ percent significance.

\subsubsection{Land surveyors}

Table 10 identified the various roles of land surveyors among the professionals in the construction industry and the ranking of the factors through the use of Relative Significance Index (RSI).

Table 10: Relative Significance Index (RSI) of the roles of the land surveyors in the Nigerian construction

\begin{tabular}{llllllllll}
\hline Roles & $\mathbf{1}$ & $\mathbf{2}$ & $\mathbf{3}$ & $\mathbf{4}$ & $\mathbf{5}$ & Total & TWV & RSI & Rank \\
\hline Building location survey & 0 & 0 & 5 & 30 & 165 & 200 & 960 & 0.96 & 1 \\
Foundation location & 15 & 40 & 40 & 50 & 55 & 200 & 690 & 0.69 & 3 \\
Preparing construction layout & 10 & 75 & 25 & 30 & 60 & 200 & 670 & 0.67 & 4 \\
Providing proposed site plan & 10 & 45 & 50 & 25 & 70 & 200 & 730 & 0.73 & 2 \\
\hline
\end{tabular}

The roles of land surveyors in the Nigerian construction industry and revealed that Building location survey ranked first with RSI value of 0.96 (i.e. 96 percent significance), Providing proposed site plan ranked second with RSI value of 0.73 , Foundation location ranked third with RSI value of 0.69 , and Preparing construction layout ranked fourth with RSI value of 0.67 . The result also showed that all the roles are significant with the least role having 67 (0.67) percent significance.

\subsubsection{Town planners}

Table 11 identified the various roles of town planners among the professionals in the construction industry and the ranking of the factors through the use of Relative Significance Index (RSI).

\section{Table 11: Relative Significance Index (RSI) of the roles of the town planners in the Nigerian construction}

\begin{tabular}{|c|c|c|c|c|c|c|c|c|c|}
\hline Roles & 1 & 2 & 3 & 4 & 5 & Total & TWV & RSI & Rank \\
\hline Designing layout and drafting design statement & 0 & 5 & 5 & 45 & 145 & 200 & 940 & 0.94 & 2 \\
\hline Protecting environment and architectural heritage & 0 & 5 & 35 & 40 & 120 & 200 & 890 & 0.89 & 3 \\
\hline Road utility design survey & 5 & 5 & 5 & 20 & 165 & 200 & 950 & 0.95 & 1 \\
\hline
\end{tabular}

The roles of town planners in the Nigerian construction industry and revealed that Road utility design survey ranked first with RSI value of 0.95 (i.e. 95 percent significance), Designing layout and drafting design statement ranked second with RSI value of 0.94, and Protecting environment and architectural heritage ranked third with RSI value of 0.89 . The result also showed that all the roles are significant with the least role having 89 (0.89) percent significance.

\subsubsection{Quantity surveyors}

Table 12 identified the various roles of quantity surveyors among the professionals in the construction industry and the ranking of the factors through the use of Relative Significance Index (RSI).

Table 12: Relative Significance Index (RSI) of the roles of the quantity surveyors in the Nigerian construction industry

\begin{tabular}{|c|c|c|c|c|c|c|c|c|c|}
\hline & 1 & 2 & 3 & 4 & 5 & Total & TWV & RSI & Rank \\
\hline Preparing bill of quantity & 0 & 0 & 0 & 5 & 195 & 200 & 1000 & 1.00 & 1 \\
\hline Schedule of materials of building of project & 5 & 30 & 15 & 75 & 75 & 200 & 790 & 0.79 & 4 \\
\hline Estimate cost relating to construction materials, time and & 0 & 5 & 0 & 45 & 150 & 200 & 940 & 0.94 & 2 \\
\hline $\begin{array}{l}\text { Variation of work in progress and materials on site for } \\
\text { interim payment }\end{array}$ & $\begin{array}{l}0 \\
15\end{array}$ & $\begin{array}{l}5 \\
45\end{array}$ & $\begin{array}{l}30 \\
20\end{array}$ & $\begin{array}{l}60 \\
50\end{array}$ & 105 & 200 & $\begin{array}{l}870 \\
760\end{array}$ & 0.87 & $\begin{array}{l}3 \\
5\end{array}$ \\
\hline
\end{tabular}

The roles of quantity surveyors in the Nigerian construction industry revealed that Preparing bill of quantity ranked first with RSI value of 1.00 (i.e. 100 percent significance), Estimate cost relating to construction materials, time and labour and cost adviser ranked second with RSI value of 0.94, Variation of work in progress and materials on site for interim payment ranked third with RSI value of 0.87 , Schedule of materials of building of project ranked fourth with RSI value of 0.79, and Cash flow payment ranked fifth with RSI value of 0.76 . The result also showed that all the roles are significant with the least role having $76(0.76)$ percent significance.

\section{Discussion of findings}

This paper presented the findings of the analysis of the questionnaires distributed to professionals in the construction industry to analyse the roles of the various professionals in the construction industry.

Every professional within the industry is an emphatic specialist in his field and should be considered as such. Construction is a team work. Each professional contributes his knowledge as a part of the whole for a 
successful building production. The construction of a building project of any kind involves the services of many people, directly, who design, construct and maintain it from inception to completion, and to terminal demolition. Construction is one of the most important activities of any economy and a large proportion of the country's resources are usually used in the construction and maintenance of building. This is in agreement with the position of Fadamiro and Ogunsemi, (1996), Mu'azu (2002), and Omole (2000).

\section{Conclusion}

The major role of construction professionals in the Nigeria's construction industry among professionals as identified by this research and it is noticeable among professionals within the industry. The professional standards include skill, competence, or character expected of a member of a highly trained persons and professional encourage the use of professionals instead of amateurs. The interplay of the forces of mutual understanding among the professionals could encourage the team spirit, a necessary parameter, in the successful execution of a project within the planned project duration. The in itself could have its added advantages to encourage the professionals to increase their productivities.

\section{Recommendation}

The government of the Federal Republic of Nigeria established Councils for the regulation of the practice areas of the distinct professional bodies within the construction sector. The specific functions, duties and responsibilities were well spelt out. The study recommended that there should be strict regulations and implementation of laws by the body of each profession guiding against some particular overlapping among professionals in the construction industry.

\section{References}

[1]. D.A. Mu'azu, The role of the Professional Builder in the Nigerian Construction Industry. ATBU journal of Environmental Technology, 1(1), 2002 29-31.

[2]. A.O. Omole, Quantity of Professional Services and Ethics. The Quantity Surveyor: A Journal of the Nigerian Institute of Quantity Surveyors, 2000, 33:2-7.

[3]. D.R. Ogunsemi., O.S. Oyediran, and D.O. Ekundayo, Construction Professionals and Project Management Competencies in Nigeria. Journal of Construction Vol.1 No. 22008 www.constr@ crown.co.za

[4]. K. Abdul-Rashid, and S.F. Hassan, Capability of a Country's Construction Industry to Combat Poverty: A Case Study on the OIC Member Countries. Proceedings of the $4^{\text {th }}$ MICRA Conference, Kuala Lumpur, Malaysia, 04(22), 2005,-04(36).

[5]. A.A. Odunlami, The Professional Builder. Being the Text of an Invited Paper Presented at the Symposium on the Role and Place of Builders in an Environmental Profession organised by Building Student's Association (BUSTA) held on Thursday $6^{\text {th }}$ March, 1997 at the School of Environmental Studies Block, The Federal Polytechnic, Ado-Ekiti.

[6]. J.O. Fadamiro, and D.R. Ogunsemi, Fundamentals of Building Design, Construction and Materials, $1^{\text {st }}$ Edition, (Fancy Publication Limited, Ile-Ife, 1996).

[7]. Encarta Dictionaries, Encarta Premium DVD, Electronic Dictionaries on Information systems, 2009

[8]. H. Abdul-Rahman., C. Wang, and X.W. Yap, How Professional Ethics Impact Construction Quality: Perception and Evidence in a Fast Developing Economy. Scientific Research and Essays Vol. 5(23), 2010 pp3742-3749, http://www.academicjournals.org/SRE

[9]. B. Greenhalgh, Practice Management for Land, Construction and Property Professionals. (Chapman and Hall, New York, 1997).

[10]. D. Appelbaum, and S. Lawton, Ethics and Profession. (Prentice Hall Publishers, Englewood, Cliffs, 1990).

[11]. J.L. Carey, and W.O. Doherty, Ethical standards of the accounting profession. (American Institute of Certified Public Accountants, New York, 1968).

[12]. A. Brien, A. (1998): Professional Ethics and the Culture of Trust, J. Bus. Stud., 17, 1998, 391-409.

[13]. S. Zantanidis, and G. Tsiotras, Quality Management: A New Challenge for the Greek Construction. (Total Quality Management, 9(7), 1998, 619-653).

[14]. T.M.S. Elhag,. and A.H. Boussabaine, Evaluation of Construction Costs and Time Attributes, Proceedings of the $15^{\text {th }}$ ARCOM Conference. (Liverpool John Moores University, 2, 1999, 473-480).

[15]. O.O. Faniran, The Role of Construction Project Planning in Improving Project Delivery in Developing Countries: Case Study of the Nigerian Construction Industry. Proceedings of the $1^{\text {st }}$ conference of CIB TG 29 on construction in Developing Countries: Construction Industry Development in the New Millenium. (The Pan Pacific, Singapore, 1999). http:/buidnet.csir.co.za/cdcproc.docs/1 ${ }^{\text {st }}$ procedings.htm1\#key

[16]. A.B. Idrus, and J.B. Newman, Construction Related Factors Influencing Choice of Concrete Floor Systems, Construction Management and Economics, 20,2002, 13-19.

[17]. J. Kangwa, and F. Olubodun, An investigation into Home Owner Maintenance Awareness, Management and Skill-Knowledge Enhancing Attributes, Structural Survey, 21(2).2003,70-78.

[18]. A.A. Oladapo, The Impact of ICT on Professional Practice in the Nigerian Construction Industry. (The Electronic Journal on Information Systems in Developing Countries. 24(2), 2006,1-19) http://www.ejisdc.org 